\section{OP-357 ヒト精漿中に存在する生理活性物質とその 加龄に伴う変化に関する研究}

\begin{abstract}
帝京大学 医学部 泌尿器科学教室 ${ }^{1}$ 明治薬科大学 薬学部 生体識能分析学研究室 ${ }^{2)}$

清水 弘文", 芦沢 好夫", 足立 陽一", 岩㴊 正之"

遠山裕一" ${ }^{1}$, 四倉 正已", 友政 宏", 押尾 茂”

飯泉 達夫" ${ }^{12}$ 梅田 隆"), 松田 兆史 ${ }^{21}$

【緒言】七卜精槳中には酵素を含む生理活性物質の存在が報告されている が、その生理学的意義については不明のものが多い。我々は主として精液 液化過程に関与すると推定される生理活性物質に着目し、その活性また は含有量測定を行い、さらにそれらの加龄にともなう変化を検討した。対象 および方法比精夜はインフォームドコンセントを得た 20〜49 歳のボラン ティア 30 名(20、30、40 歳代、各 10 名)より提供を受けた。精液は室温で 液化後、一部を一般精液検査に用い、残りを遠心分離し、精槳を分析まで $-80^{\circ} \mathrm{C}$ で保存した。これらの精槳を用いて、組織かリクレイン (TKK)、塩基 性アルギニンアミダーゼ(BAA)、ロイシンアミノペプチダーゼ様アリールアミ

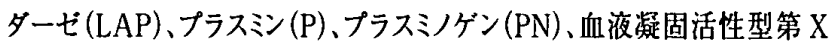
因子(FXa)、前立腺特異抗原(PSA)の測定を行った。結果】検体の精液 性状は、各年代間で有意差が認められなかった。一方、測定した各種生理 活性物質は、加龄によってその濃度が減少することが認められ、特に、精液 の凝固・液化系に関与していると考えられる、Fxa、P、PNの活性濃度は加 路により顥著に減少していた。結論】今回検討した物質の生理学的意義 は不明だが、精夜性状の加齢による変化を考察する際には、精槳中生理 活性物質の変動を考慮する必要があると考えられる。
\end{abstract}

精漿 加龄 生理活性物質

\section{OP-358 SRY 陰性 XX male 症例からみた性分化 のメカニズム}

\section{名古屋市立大学 医学部 泌尿器科"1 基礎生物学研究 所 細胞分化研究部門 ${ }^{21}$}

小島 祥敬", 林 祐太郎", 黒川 覚史", 水野 健太郎"

宇田 晶子", 郡 健二郎", 諸橋 憲一郎 ${ }^{21}$

【目的】SRYは精紧決定因子とされていたが、臨床症例の検討か ら、性分化は必ずしもSRYに依存しないことがわかってきている。 の点を確かめる目的で、最近同定されてきた性分化に必須の下記 数種類の䎐写因子が SRY 陰性 XX male 精巣に発現するか検討 した。対象】当院泌尿器科で経験したXX male 症例 4 例である。 いずれも小児期に外陰部異常を指摘されている。れらに対し(1) PCR 法および FISH 法によるSRY 遺伝子の有無 (2)精巣に拊る RT-PCR 法によるAd4BP/SF-1、DAX1、GATA4、WT1、SOX9 mRNAの発現の有無と免疫組織染色法によるこれら因子の発現と 局在について検討した。結果I(1)いずれもSRY 陰性であった。 (2)精巣ではいすれれの転写因子の mRNAの発現は認められ、その 蛋白の局在はAd4BP/SF-1、DAX1、GATA4 は Sertoli 細胞およ び Leydig 細胞の核内に、WT1は Sertoli 細胞の核内に発現して おり、正常の精巣と一致していた。たこれらにより制御されていると MIS の発現は、い゙れの精单の Sertoli 細胞の細胞質内に認めた。 [考察]生殖腺の分化を支える遗伝子発現カスケードを考える上で、 SRY の存在の有無に関わらず、これら因子の発現を認めたことは、 男性への分化に必ずしもSRY が必須ではないことが示㖫された。 $X X$ male SRY 性分化

\section{OP-359 思春期外来における性分化異常症男児の 検討}

\section{名古屋市立大学 医学部 泌尿器科}

小島 祥敬, 林 祐太郎, 中根 明宏, 浅井 伸章, 丸山哲史 最上 美保子, 最上 徹, 郡 健二郎

【目的】性分化異常症患者の思春期以降のホルモン動態や性機 能を中心とした臨床的検討を行った。対象】1983 年以降受診し た性分化異常症患者のうち、戸籍上男子としたもの 12 例 (XX male4 例、真性半陰陽 (以下 TH) 3 例、混合型性腺異形成症 (以 下 MGD) 4 例、アンドロゲン不応症 (以下 AIS) 1 例)である。いず れも小児期に外陰部形成術を施行した。THの染色体は 46, XX、 46, XY、46, XX/46, XY が 1 例ずつ、MGD4 例はいずれも 45, XO/46, XY であったこれらのうち長期経過観察が可能であった ものに対して、(1) 精栄容量 (2)ホルモン動態の推移 (3) 性機能に ついて検討を行った。結果了思春期以降の精宩容量はXX male 2.8-5.1ml、TH1.7-9.5ml、MGD2.0-2.2mlであった。ずれも思春 期よりLH および FSH の上昇を認め、高ゴナドトロピン性性腺機能 低下を示した。思春期以降に達した症例の性機能は、XX male3 例において勃起、射精可能であり、そのうう 2 例で性交涉可能で あった。TH1 例で勃起、射精可能であった。MGD、AIS それぞれ 1 例で勃起の及可能であった。考察】性分化異常症男児のほとん どが精巣機能の障害を認め、小児期に手術を施行し成功した症 例でも、思春期以降は樣々な恼みを持っておう、特に性機能や精神 面での長期にわたる経過観察が必要と思われた。

性分化異常症 ホルモン 性機能

\section{OP-360原発性アルドステロン症における腎賈胞の 臨床的意義}

\section{浜松医科大学 医学部 泌尿器科}

野畑 俊介, 伊藤 寿樹, 甲斐 文丈, 青木 雅信, 新保斉 高山 達也, 速水 慎介, 平野 恭弘, 影山 慎二, 牛山 知已 鈴木 和雄, 藤田 公生

【目的】原発性アルドステロン症(APA)に扔ける腎襄胞の合 併の臨床的意義について検討した【方法】当大学及び関連 施設において腎豊胞の有無を CT で確認できた APA 患者 26 例 (男女各 13 例、平均年齢 $46.1 \pm 8.4$ 歳)について臨床項 目を比較検討した。成績】腎賈胞は 26 例中 8 例 $(30.8 \%)$ に 認めた。血清かリウムの最低值はそれぞれ $2.49 \pm 0.47 \mathrm{mEq} / 1$ 、 $2.61 \pm 0.58 \mathrm{mEq} / 1$ であった。術後の血清かリウム值の正常化

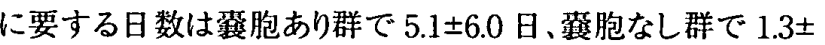
0.9 日で有意差を認めた $(\mathrm{p}=0.0475)$ 。高血圧の䧹患期間は

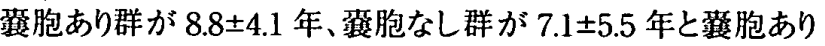
群が若干延長していた $(\mathrm{p}=0.1518)$ 。腎機能に関しては囊胞 あり群と蘘胞なし群で有意差を認めなかった $(\mathrm{p}=0.3413)$ 。(結 論]APAにおいては腎賈胞の頻度が高い。腎䔬胞の合併は 術後の血清かリウム值の正常化に影響を与える可能性があ る。

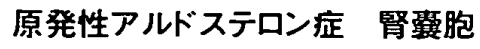

